\title{
CONSTRUCTION OF CHILDHOOD IN CHILDREN'S CINEMA IN INDIA: A CRITICAL ANALYSIS OF FOUR HINDI FILMS
}

\author{
Dr. Karuna Sharma \\ Assistant Professor in the School of Media \& Communication Studies, Doon University, Dehradun \\ DOI: 10.46609/IJSSER.2021.v06i03.008 URL: https://doi.org/10.46609/IJSSER.2021.v06i03.008
}

\begin{abstract}
The sphere of children's cinema remains rather unexplored in India despite the presence of a nodal agency like the Children's Films Society, India (CFSI). This speaks volumes about the inadequacy regarding the creative contribution in this very domain. The filmmakers don't take the required plunge and hence there is a visible dearth of cinema for children. This inadequacy in turn gives rise to other kinds of anomalies, one being the construction of childhood in a certain manner. There are no consequential, sincere and pointed discussions around the limited and restricted ways in which children and childhood are defined.

This paper tries to enlist the various 'dominant' traits associated to childhood and to find out if there have been enough efforts in order to break free from the age-old notions and ideas about children. The paper chiefly analyses four films critically and tries to decipher the various meanings related to childhood.
\end{abstract}

Keywords: Children, Childhood, Children's Cinema, Construction, Dispositive analysis, Social Semiotic Theory.

\section{INTRODUCTION}

The media effects studies, since time immemorial, have talked in detail about the impact of certain communications, (or media as a whole) on audiences with special focus on children. This kind of attention towards 'media effects on children' is required but only partially. The real problem stems from the unavailability of content specific to children. The need to produce content for children is pressing as its absence would lead to 'children's consumption of 'adult' media.

Yet another pertinent issue is 'the notions about childhood' that prevail within a context and their reflection in the cinema. The dearth of children's (media) entertainment as a problem becomes more severe when the portrayal of children in the available outlets is inspected. There seem only certain number of ways in which the child characters are written or defined in the films made for 


\section{International Journal of Social Science and Economic Research}

ISSN: $2455-8834$

Volume:06, Issue:03 "March 2021"

them and otherwise. There is a great deal of homogeneity in looking at children and believing that there are some traits that they are bound to possess.

In their book, In Front of Children: Screen Entertainment and Young Audiences, Cary Bazalgette and David Buckingham write, “.... children have predominantly been seen as the province of psychology, as if they were effectively devoid of social experiences. Children, it would seem, are implicitly regarded as asocial, or perhaps pre-social. This emphasis has had several consequences. [.....] The cognitivist notion of childhood as a steady progression towards achievement of adult rationality is effectively based on the kinds of oppositions between adult and child. Here again, children are defined in terms of what they apparently cannot do, such as think 'logically'- rather than in terms of what they can do. And it is supposed to be a condition of true adulthood that 'immature' and 'irrational' thinking is left behind. (Buckingham, 1995)

This leads to a particular kind of meaning making in relation to childhood where certain dominant attributes are portrayed as being intrinsic to it. This also leads one to a fundamental question of how adults imagine the child audience. The visual representations of children and childhood are symptomatic of an all-pervasive notion or idea about childhood which is not always true. Therefore, an inspection of films to study the 'construction of childhood' is required in order to enlist the traits filmmakers associate with childhood and hence present in their films.

A significant subsidiary of this issue is the definition of child based on the age. To put it differently, till which age a person is considered a child is an essential question. In India "...the very definition of the word 'child' according to Indian laws remains ambiguous. In the country, different laws define the words 'child' and 'minor' differently." (Sikdar, 2012) Hence, it becomes important to also investigate the absolute age of defining childhood that the filmmakers adhere to when making films for children. However, as Jean Piaget has defined various stages of Cognitive Development namely pre-operational (aged 5 years and below), concrete operational (6-11 years) and formal operational period (11-12 years), (Piaget, 1962) probing into the films made for children in India, the age group targeted seems to fall between 5 years to 14 years.

The Hindi film industry, also colloquially called Bollywood, ranks highest in the world for producing highest number of films every year. In terms of the number of films produced each year, Bollywood is firmly on top of the pile with 1,602 in 2012 alone. The U.S. churned out 476 films that year while the Chinese managed 745. In the same year, Hollywood sold 1.36 billion tickets compared to Bollywood's whopping 2.6 billion.” (McCarthy, 2014)

This very fact finds a mention here as in these humongous figures, the numbers of the films made for children (per year) is insignificant despite the presence of the Children's Films Society, India (CFSI), a nodal agency responsible for the production of films for children in the country. 
International Journal of Social Science and Economic Research

ISSN: 2455-8834

Volume:06, Issue:03 "March 2021"

Hence, in the dearth of cinema for children it becomes pertinent to look into representational aspects of children in this very genre that is avouched to be for their entertainment.

Therefore, this research paper examines the construction of childhood in four Hindi children's films; two produced by the Children's Films Society, India (CFSI) and two produced by independent producers/production houses, and attempts an enlistment of the various traits that are associated to childhood and children. It also tries to critically examine whether these defining traits are a result of a dominant understanding and that how representative are these associations of the children.

\section{CONSTRUCTION OF CHILDHOOD}

The constructs of any social concept are a derivative of the social reality regarding it. Arts, in general, and cinema, in particular, base its foundation on the cultivated and accepted social ideas. Nonetheless, the role of cinema in challenging certain overriding concepts should not be put down but the existence of such ventures is limited to a small number. In a world that is predominated by market dynamics, cinema doesn't remain untouched. Also, when specifically looking into the domain of children's films, the audience (children's) reception is pre-conceived and audience dynamics is oversimplified.

The phrase Invisible Audience for children, used by Cary Bazalgette and David Buckingham seems to suit the Indian context too as the children (in India too) remain unseen to the producers of the text. These statements here are a result of the examination of the realm of children's cinema where plunge taken in by the filmmakers is very limited.

However, as mentioned the primary aim of this study is to find out the various constructs for operationalizing childhood. The films included in this study are: Chillar Party (Tiwari \& Bahl, 2011), Gattu (Khosa, 2012), Kaphal..Wild Berries (Mukhtiar, 2013) and Dhanak (Kukunoor, 2016). The films Gattu (Khosa, 2012) and Kaphal.. Wild Berries (Mukhtiar, 2013) are produced by CFSI while Chillar Party (Tiwari \& Bahl, 2011) and Dhanak (Kukunoor, 2016) are produced by independent filmmakers/producers.

\section{METHODOLOGY}

Cinema replicates society. The cultural products in any society are reflective of it. This leads to concluding that the formative elements of any cultural product mirror the concepts and representations in that society. Cinema has visual and aural components and is loaded with various signs. Children's cinema is no different. Hence, to understand the cinema of a society these signs and their meanings in the particular contexts ought to be studied. 


\section{International Journal of Social Science and Economic Research}

ISSN: $2455-8834$

Volume:06, Issue:03 "March 2021"

The Social Semiotic theory makes the basis of this study which states that signs do not stand alone, rather can't be read in isolation. Two important things need to be considered, first, that Cinema is profuse with signs and second that cinema is a reflection of society. Hence it is pertinent to investigate how similar is this manifestation of society with the actual world. This enquiry becomes all the more needed when the cinema is being created for children. (Carbon, 2007)

After determining the theoretical framework, it was decided that a dispositive analysis would be conducted to note down the various traits/characteristics associated with childhood.

As understood, human beings derive their knowledge from the surroundings that they are born in. These surroundings are made up of linguistically performed practices, non-linguistically performed practices and the materializations which are observed and hence knowledge derived. Through dispositive analysis all these three elements were observed and noted, and in context of this study a list of childhood constructs could be compiled.

\subsection{Defining Children's Cinema}

a. Language: The study aimed to examine the films for children but given the diversity in the country it became imperative to select a parameter to achieve some standardization in this randomness. Hence, language was chosen as that parameter which would make the universe uniform. Consequently, the study focused on the Hindi language cinema for children.

b. Time-line: The Hindi language cinema for children had to be bound in a time frame to achieve some more uniformity. Hence the period between 2008 and 2018 was chosen for contemporary relevance.

Also, animated films were not included in the study as the very domain of animation films is too vast and needs to be looked into separately. In addition, animation as a genre has gained impetus in the recent years in India, and though there were attempts made in this domain as early as 1956 (the Banyan Tree) yet the time frame required to study these films is different. (CFSI)

Also, the incorporation of CFSI in 1955 had to be considered before outlining a definition of children's cinema to highlight the official recognition gained by this genre.

Looking at the above pointers a definition of Children's Cinema for this study was proposed which is: "Children's Cinema, for the purpose of this study, would be defined as all the Hindi language live action films produced for children in the years between 1955 to 2018 ".

Out of the four films selected, three have been the National Award winners for the Best Children's film in their respective years. While the fourth film, Gattu (Khosa, 2012), has 


\section{International Journal of Social Science and Economic Research}

ISSN: 2455-8834

Volume:06, Issue:03 "March 2021"

received accolades at many national and international film festivals. The films have been chosen from both the production centres viz. CFSI and non-CFSI or Independent filmmakers.

This was done as the state-funded films (CFSI films) thrive on subsidies; also their content is under close watch and censorship. While the films not funded by the state have more budget and less censorship in the production stage. Thus, the two production centres (might) lead to a difference in content and presentation of films, hence making them diametrically different. Therefore, two separate categories were maintained.

On the basis of the literature reviewed, some overriding concepts that are generally used to define 'childhood' were listed down. The children are believed to possess some qualities and hence the portrayal. A list of such qualities (or variables) was made and these variables were identified under three heads- i) Linguistic Practices, ii) Non-linguistic Practices, and iii) Materializations. After operationalizing the definition of 'childhood', based on these variables, a preliminary study was undertaken where four films were studied to check the presence of the above-mentioned variables pertaining to 'childhood'.

The initial study was done using four films from the collected database to define 'construction of childhood'. The films that formed a part of this preliminary study were- Masoom (Bose, 1960), Abhay...The fearless (Kapoor, 1995), Kabhi Pass Kabhi Fail (Saini, 1999) and Ek Ajooba (Advani, 2000). The films were randomly selected from a comprehensive database of children's movies.

The preliminary study provided a starting point and helped in identifying more variables defining 'childhood' on screen. Apart from the pre-conceived variables, some other variables were noticed during the analysis of the films and these were then added to the list of variables for the main analysis of 4 films. Therefore, a new list of variables included the pre-thought variables as well as the new variables as identified during the preliminary study.

The following variables were noted:

\begin{tabular}{|c|c|c|}
\hline Linguistic Practices & $\begin{array}{c}\text { Non-Linguistic } \\
\text { Practices }\end{array}$ & Materializations \\
\hline Argumentative & Possessive & Books (a dislike for) \\
\hline Inquisitive & Playing Pranks & $\begin{array}{c}\text { School bags, Pen } \\
\text { /Pencil/ Other } \\
\text { stationery (being } \\
\text { possessive for }\end{array}$ \\
\hline Indecisive & $\begin{array}{c}\text { Indulging in } \\
\text { unnecessary fights }\end{array}$ & Cycles/Bicycles \\
\hline Immature & Weeping \& Shouting & Toys (dolls, planes, \\
\hline
\end{tabular}


International Journal of Social Science and Economic Research

ISSN: 2455-8834

Volume:06, Issue:03 "March 2021"

\begin{tabular}{|c|c|c|}
\hline & & guns, etc.) \\
\hline $\begin{array}{c}\text { Disinterested in } \\
\text { Studies }\end{array}$ & Revengeful & Video games/T.V. \\
\hline
\end{tabular}

\section{1 (a) List of Variables observed in films used for constructing childhood}

However, there was a possibility of more variables being added to the above list [3.1 (a)] with every new (film) analysis and therefore, the final list at the end of the analysis having some more variables. Hence, an open approach was followed so that if any new variables are identified, then these could also be included in the final analysis.

Also, if in some cases the construction of childhood was contradictory to the mentioned parameters (in the list) then those instances were noted down.

\section{ANALYSIS}

\subsection{Synopsis of the films}

All four films have different plots and settings. Kaphal (Mukhtiar, 2013) is set in a small village in Uttarakhand and is a story of two brothers Makar and Kamru who have never seen their father as he is lives in the city for earning money. The father has not visited the village for five years. The kids have forgotten their father and are now excited to receive the news of his arrival. They wait for him and for their gifts in anticipation. The father does come but with his own bundle of problems; no money, a police case and no job. The first disappointment comes when the boys didn't like the toys which were supposedly brought by their father. In due course, the boys, especially Makar, start hating his father as he is strict, directs them to school and makes them study.

He decides along with his friends and brother, Kamru, to seek help from the rumored village witch Pagli Dadi who lives on a hill top. He plans to request the witch to cast a spell that would force the father to go back to the city. What follows is a joy ride full of adventures and merriment, concluding in the boys bonding with their father.

Gattu (Khosa, 2012) is set in a small town in central India where kids and adults are equally obsessed with kite-flying. The airspace is dominated by a black kite called Kali with mysterious origins. Gattu, a street kid, dreams of defeating Kali but fails. He discovers that the local school has a roof which will give him a vantage point. Impersonating as a student he sneaks into the school and must now pretend to study. The only problem -- he is illiterate! Nonetheless, the little street urchin takes up the challenge. Dreams aren't impossible when the desire is strong. (IMDB) The film unwinds the gradual liking that Gattu develops for the school and his friends. 


\section{International Journal of Social Science and Economic Research}

ISSN: $2455-8834$

Volume:06, Issue:03 "March 2021"

Dhanak (Kukunoor, 2016), revolves around the undeterred determination of a sister recounted through her journey (along with her brother) of trying to meet Shah Rukh Khan, the superstar, and to seek his support to help her brother regain his eyesight. Her belief that the superstar can help them stems after seeing a poster where the star is seen promoting eye donation. The film beautifully pictures the uncomplicated world view that children have and how this consolidates their inner strength to achieve something that the adults might not find very practical. This belief leads Pari to embark on a journey, along with her brother, that is full of hurdles and difficulties, but ends on a positive note. The main theme of the movie is determination and strong will lead to success.

'Love for animals' is the central theme in Chillar Party (Tiwari \& Bahl, 2011), where the children residing in a society come together to save Bhidu, a dog, from a "scheming politician who plans to get rid of stray dogs" [The Economic Times (Online)] The sub-theme in this film is friendship as it showcases the solidarity the kids from well-off families show for an orphan kid who is employed in their society. The friendship between the kids of the society with Phatka, an orphan kid who is employed in the same society, accentuates the quality of children who are above class and status.

\subsection{DISPOSITIVE ANALYSIS}

\section{2 (a) Linguistic Practices}

When looking at the linguistic practices, a common construct that the investigator came across was the children being argumentative and inquisitive (in these films). When dealing with this probing attitude implying a positive approach, children are portrayed as being inquisitive but when projected negatively they are shown to be argumentative.

In Chillar Party (Tiwari \& Bahl, 2011), the story revolves not just around one or two child protagonists, but an entire group. Here most of the children seem mischievous and argumentative barring a few, e.g. a character named Balwan alias Janghiya is confrontational but in a very amusing and witty manner. Another one, Arjun alias Encyclopedia is sharp and logical and though he has all the answers to all the things yet is always pacified and controlled.

In Gattu (Khosa, 2012), the kid Gattu prods his uncle now and then with repetitive questions. He is also inquisitive (positively argumentative) and keeps on asking various questions. At one instance, he asks his uncle (22mins 46 secs), "When will my father come?" The response from his uncle corresponds to the fact that the question is not new rather it has been asked at various other instances by him. Later, when Gattu secretly starts visiting the school, he is seen asking questions to his non-school going friends to flaunt off his knowledge. But in all these occasions of questioning, he always comes across as mischievous kid who is definitely not argumentative! 


\section{International Journal of Social Science and Economic Research}

ISSN: $2455-8834$

Volume:06, Issue:03 "March 2021"

Chotu's character in Dhanak (Kukunoor, 2016) is sketched as being both argumentative and inquisitive. His sister Pari, who is elder to him, is only inquisitive; corresponding to the relationship of logic being the prerogative of the adults. Pari's brother asks questions to everybody till the point of argument. In the introductory scene, (1 min 18 secs), he disagrees with his sister when she says, "Shah Rukh rahega number one" (Shah Rukh shall always rule the film industry), and he in turn says, "Salman rahega number one" (Salman shall always rule the film industry). Shortly after this, he snaps at his aunt saying, "Jhooti, paanch rotiyan daab rakhi hain us dabbe mein" (Liar, there are still five breads in that box). On the other hand, Pari, is quiet and non-quarrelsome. This yet again strongly underscores the perceived ideas of adulthood and childhood. Pari is 'adult-like' while Chotu is 'child-like'.

Chotu becomes friendly with all the strangers they meet during their journey to Jaisalmer, while Pari is more cautious, a trait which is associated with adults.

A blithe Chotu, tells the first stranger they meet on their journey about the motive with which they have started but Pari lies to him about the place they had set to visit. On being asked by Chotu the reason for this lie, she says, (34mins 23 secs) "Itni ajeeb si baat pe kaun bharosa karega?" (Who's going to believe such a strange thing?)

In adulthood, realism overpowers creativity and hence Pari, though has set on a prodigious journey like this, finds it embarrassing to share it with anyone. This marks a stark difference between a child and an adult.

The instances of children being argumentative are rare in Kaphal (Mukhtiar, 2013). Although, in one instance, when Kamru argues the mother slaps him hard. The power differential is much visible in this film, though it can be deduced that there is an intended effort by the director to not tamper with the reality of childhood. To elaborate, the children in economically deprived and difficult spaces, like that in Kaphal (Mukhtiar, 2013), have to bear the brunt of the resourcelessness of their parents. In conditions like these, where basic facilities are not available to people, children and their aspirations remain unattended. The mother slapping Makar is also symptomatic of the power differential which otherwise also is a huge reality and where children remain at the receiving end, and parents at times vent out their frustrations and anger on them. The children here (in the movie Kaphal) are mostly silent when with their parents. They giggle, laugh and play, secretly though, when with them. Although, the kids in this film are inquisitive as they ask each other a lot of questions pertaining to Pagli Dadi, their father, etc.

Another construct is the (assumed) immaturity of (and in) the children. This construct probably stems from the simplistic outlook that children have for and towards the world. The depiction of this characteristic also swings between negative and positive. Immaturity, in these films, could 


\section{International Journal of Social Science and Economic Research}

ISSN: $2455-8834$

Volume:06, Issue:03 "March 2021"

be seen touching two opposed associations. At times children were seen inviting troubles while at other times they revealed their most imaginative aspects.

All the films Gattu, Chillar Party, Kaphal and Dhanak, eulogize the joys of childhood and highlight the simple and straightforward stance that children have even for the biggest problems they face. School friends believing Gattu's story of a bomb being planted inside the premises of the school, the society kids conducting a rally for saving Bhidu, the dog (in Chillar Party), Pari's journey to meet the superstar Shah Rukh Khan to request him to sponsor his brother's eye operation (in Dhanak), and Makar's quest to meet the village witch to send away his father back to the city may seem immature but translate to different virtues that kids possess.

In each of the above-mentioned instances there is a deeper linkage to different characteristics children possess e.g., Gattu and Chillar Party showcase the importance of friendship, Dhanak and Kaphal highlight the undeterred determination that kids can have due to their naive stance.

However, as mentioned, in all of the films both aspects of immaturity are being associated to kids. For instance, in the movies Chillar Party and Dhanak, the gang's and Pari's decision to take up mammoth tasks of fighting the politician and meeting the superstar respectively put them into problematic situations. While in Gattu and Kaphal, the children are shown guilt-stricken, only to realize the importance of relationships.

Being disinterested in studies, rather a dislike for school was seen only in Kaphal (Mukhtiar, 2013) where the kids would often miss their schools and play in the jungle all day long. While in Dhanak (Kukunoor, 2016) and Chillar Party (Tiwari \& Bahl, 2011), the kids were shown making no excuses for going to school, the plot in Gattu (Khosa, 2012) revolves around a boy who develops a liking for studying in his quest to find the black kite, Kali.

\section{2 (b) Non-Linguistic Practices}

Another probe into the filmic text was made to note down the various non-verbal customary associations to describe a kid's character. Here, some common traits with respect to children being indulged in various activities, across movies, could be identified.

The first important non-discursive element used in the characterization in these films was the kids indulging in unnecessary fights. In various instances in the movies under study, this trait could be noticed. The kids gang up against Phatka, the new society cleaner, for no concrete reason in Chillar Party (Tiwari \& Bahl, 2011). Similarly, in one of the instances in Dhanak (Kukunoor, 2016) (5mins $51 \mathrm{secs}$ ), a boy Bhanu unnecessarily blocks Pari's and Chotu's way. 


\section{International Journal of Social Science and Economic Research}

ISSN: $2455-8834$

Volume:06, Issue:03 "March 2021"

However, in the movie Kaphal (Mukhtiar, 2013), Makar and Kamru are shown playfully fighting with each other. Gattu (Khosa, 2012) has no instances of kids indulging in unnecessary fights.

Presenting kids as being possessive is another feature that could be identified in some of these films. This trait too, is seen touching the two extremes of being responsibly proprietorial (positive) and of being jealous (negative). Also, a slight addition in this approach is the perception of children being possessive for their relationships. However, in this case the idea is inclined towards a positive tone. The examples of this is the belongingness for a new friend, Phatka, and his dog, Bhidu, that lets the kids of Chandan Nagar Colony take up a mammoth challenge of confronting a politician, in the film Chillar Party (Tiwari \& Bahl, 2011), substantiates the property of possessiveness that kids have. Similarly, in Kaphal (Mukhtiar, 2013), Makar's friend is shown to be too possessive about his toys particularly a remotecontrolled plane. In Gattu (Khosa, 2012) possessiveness for relationships is placed on a higher podium than possessiveness for the material things. Likewise, in Dhanak (Kukunoor, 2016), the relationship between Pari and her brother is very thick and beyond material aspirations.

In all of the films except Gattu, being revengeful is also a trait that is associated with the children. In Chillar Party, the kids want to take revenge upon a neighbour who taunts them whenever they lose a match. One of the kids announces (5min $38 \mathrm{secs})$, "Jis din jeet gaye na, kasam se, iske ghar pe sutli bomb zaroor phodeinge" (The day we win, I swear, will blast a bomb at his place). They also materialize this plan (28 mins 45 secs) after being victorious in a match.

Upon being reprimanded by their father, Makar and Kamru (in Kaphal) plan to seek revenge by employing Pagli Dadi to make their father return to the city.

Playing pranks is another non-linguistic trait that could be identified in some of the films. Gattu plays the prankster by befooling his friends and classmates by telling them that he is a secret agent! Creativity abounds when the group of kids, in Chillar Party, decide to create dog feces with flour and colours. In Dhanak, Chotu (1 hr 02 mins 43 secs) fools Pari, who alarms her against taking any eatables from strangers. He enacts of getting choked after eating a chocolate bar given to him by a foreigner they meet during their journey.

A fifth non-verbal trait is being carefree. To put it differently, children are presented as being happy and uncomplicated. Pari and Chotu in Dhanak, despite being faced by a problem as grave as Chotu's blindness, are carefree and blissful. While going to their school daily, they narrate stories of the films of their favourite movie stars. Though they are not completely oblivious of their life's problems yet they are basically very joyous. In the same way, Gattu belongs to a rather impoverished background yet he is carefree and liberated. His conditions don't dominate 


\section{International Journal of Social Science and Economic Research}

ISSN: $2455-8834$

Volume:06, Issue:03 "March 2021"

him and he, like any other child, is mirthful. In Kaphal, the kids are blithe and easy going and despite their conflict with the father, remain happy. In Chillar Party, the groups of children are cheerful and euphoric.

Another regular construct is the playfulness in children that borders the mischief. The kids are being shown as naughty in all the films. The researcher identified imaginative and mischievous as two variables, but feels that mischief is also a translation of being imaginative. The kind of pranks that children are shown to be indulged in speak volumes about the creativity that is required to plan such activities.

One more expression that is associated with children is shouting. Though, technically not entirely non-verbal, it is used to portray both happiness and sadness in children. Yet another expression noted in these films was weeping. In almost all the films children wept for various reasons.

\section{2 (c) Materializations}

The various materials and objects that had strong linkage with childhood and children in these films, as identified, were cycles, books, pen-pencil, kites, gadgets, colours, bags, sweets, ice creams, etc.

Some materials remained common across all films under study, e.g., books, pen-pencil, bags etc. as school forms a big part of the child reality. Other common objects that were seen in most of the films were cycle, colours, toys (bat and ball, etc).

In Gattu, a kite is associated to childhood and a child's desire to soar high and beat the unknown competitor to earn accolades; hence drawing a linkage to children.

In the movie Chillar Party, the group of children is shown with cycles, football, etc. emphasizing the playfulness in them and hence depicting childhood through these material objects.

In Dhanak (Kukunoor, 2016) and Gattu (Khosa, 2012), school going is an active part of the plot and hence describing childhood through books, bags, pen/pencil, etc. can be noted.

\section{DISCUSSION}

The narrative structure in all the films is similar, though the presentation differs in quite a few ways. The films produced by CFSI have low-budget realist aesthetic while the other two films have sophisticated production quality. However, all four films are readily recognizable as children's films yet there are prospects for serving the adult pleasures and offering an adult point of view. This is more visible in the non-CFSI films, Dhanak (Kukunoor, 2016) and Chillar Party 


\section{International Journal of Social Science and Economic Research}

ISSN: $2455-8834$

Volume:06, Issue:03 "March 2021"

(Tiwari \& Bahl, 2011), where the profit motive couldn't be compromised. In these films, the children seemed to inhabit a certain position with respect to the adult perspective. There are instances, in both films, which make thematic likeability for adult audience. For instance, the devious politician and his sidekick, in the movie Chillar Party (Tiwari \& Bahl, 2011), are the characters played by well known actors, and give a scope for the adult point of view. Similarly, in Dhanak (Kukunoor, 2016), the angle of human trafficking which makes a part of the plot (though minimalistic) offers an adult approach to the narrative. Children's cinema ought to be offering a child centric perspective whereby the inner challenges, threats; hopes and aspirations of the children can be sketched. Although, it is important to mention here that in both these films the directors Nitesh Tiwari, Vikas Bahl and Nagesh Kukunoor have shown an honest effort to sketch the story through a child perspective but the market pressure has led to the inclusion of some plot points that allow extension in the range of audience.

The other two films, Kaphal (Mukhtiar, 2013) and Gattu (Khosa, 2012), have a different approach and though there is scope for the adult perspective in these narratives yet it is largely refused. This was done through certain kinds of camera decisions. In both films the children are shot from low-angle camera which makes them look strong and powerful. The children look decisive in Kaphal (Mukhtiar, 2013) to send the father back to the town and Gattu (Khosa, 2012) pledges to defeat Kali, the invincible kite.

The music in both set of films is different. While in independent films, there is both diegetic and non-diegetic music that supports the narrative yet the CFSI films use music sparingly that too in non-diegetic manner.

In Dhanak (Kukunoor, 2016), Chotu's singing talent is showcased through different Rajasthani folk songs. There are five songs in the film. Similarly, in Chillar Party (Tiwari \& Bahl, 2011), there are 8 songs, all describing varied expressions. The song 'Hum ek thali ke chatte batte hain' (We are more or less similar) describes children being similar despite the differences they might have. This, once more, underscores the linear similarity with which adults look at children. In fact, the variables that construct childhood on screen have remained almost similar in most of the movies and have created in the public understanding, since long, commonalty in viewing children with an overriding perspective which is too simplistic and homogenous. This homogeneity regarding kids could be seen in both set of films, namely the CFSI productions and films made independently by filmmakers.

However, though the treatment of adults in these narratives has remained somewhat similar but changes with respect to them becoming less rigid in conceiving child characters on screen, are visible. The case in point here can be another song in Chillar Party, Behla do, phusla do, balon ko sehla do...hum chup ho jayeinge.... na jane kyun sab ko lagta hai yahi..bachon ka dard koi 


\section{International Journal of Social Science and Economic Research}

ISSN: $2455-8834$

Volume:06, Issue:03 "March 2021"

dard hi nahi ( You can coax us, cajole us and everything will get sorted..?? Why can't people empathize with children's grief and worries?) The director Nitesh Tiwari has directed some very good and pertinent films and one can feel that his concern is reflected in these lyrics (which are penned by him). Yet when it comes to films for children the economics seem to dominate the narrative, plots and constructions.

\section{CONCLUSION}

The power dynamics between adulthood and childhood seem to exist in films for children and also seem to define childhood in a limited number of ways. This is detrimental to the very spirit of children's cinema as the basic intention of films for children is to provide reflective avenues for kids. The main aim is to make to the children available films which they can identify with while also learning and getting entertained. The uniformity in defining children by associating with them common variables across films is a testament to the fact that less research is undertaken before conceiving child characters for children's films. The idea that all children are similar is erroneous and also leads to thematic confinement of plots in children's films.

However, it is important to mention here that with new films there seems an intended effort to break constructional stereotypes and provide a contextual clarity to child characters in children's films. Though, this inclusion is at a very theoretical level and doesn't seem to percolate at the level of social consciousness, as a result of which the non-linguistic and materialization parameters continue having the superficiality with which childhood is understood.

The child characters seem to be given some space for breathing. Given, because the power dynamics don't seem to change much, even after a span of 60 years, and what should have been an empathetic space earned by children by the virtue of society being aware, still seems lent to them by the adults.

\section{References}

Advani, S. (Director). (2000). Ek Ajooba [Motion Picture].

Bose, S. (Director). (1960). Masoom [Motion Picture]

Buckingham, C. B. (1995). In Front of the Children: Screen Entertainment and Young Audience. U.K.: British Film Institute.

Carbon, J. (2007). On the Methodology of Dispositive Analysis. Critical Approaches to Discourse Analysis Across Disciplines 1 (1): 115-123 , 112-123. 
International Journal of Social Science and Economic Research

ISSN: 2455-8834

Volume:06, Issue:03 "March 2021"

Chillar Party Movie Review. (n.d.). Retrieved September 2017, from The Economic Times (Online):https://economictimes.indiatimes.com/industry/media/entertainment/chillar-partymovie-review/articleshow/9150993.cms

Debbie Olson, G. R. (2013). Representations of childhood in the media. In D. Lemish (Ed.), The Routledge International Handbook of Children, Adolescents and Media. London: Routledge.

Fitneva, S. A. (2010). Children's Representation of Child and Adult Knowledge. Journal of Cognition and Development, 458-484.

CFSI. (n.d.). Retrieved September 2019, from Children's Film Society, India: https://www.cfsindia.org/

Gattu (Plot). (n.d.). Retrieved October 2018, from IMDB:

http://www.imdb.com/title/tt2156785/plotsummary?ref_=tt_ov_pl

Kapoor, A. (Director). (1995). Abhay ...The Fearless [Motion Picture].

Kaziaj, E. (2016). "The adult gaze": exploring the representation of children in television news in Albania. Journal of Children \& Media , 426-442.

Khosa, R. (Director). (2012). Gattu [Motion Picture].

Kukunoor, N. (Director). (2016). Dhanak [Motion Picture].

McCarthy, N. (2014). Retrieved November 2018, from Forbes-Business:

https://www.forbes.com/sites/niallmccarthy/2014/09/03/bollywood-indias-film-industry-by-thenumbers-infographic/\#61 fd302d7bf0

Mukhtiar, B. (Director). (2013). Kaphal.. Wild Berries [Motion Picture].

Piaget, J. (1962 (66)). The Psychology of the Child. NewYork: Basic Books.

Sikdar, S. (2012). Who is a Child? Retrieved November 2018, from The Hindu (Online): https://www.thehindu.com/news/national/who-is-a-child/article3528624.ece

Staples, T. (1997). All Pals Together: The Story of Children's Cinema. Edinburgh: Edinburgh University Press.

Saini, V. (Director). (1999). Kabhi Pass Kabhi Fail [Motion Picture].

Sharma, K. (Director). (1956). Jaldeep [Motion Picture]. 
International Journal of Social Science and Economic Research

ISSN: 2455-8834

Volume:06, Issue:03 "March 2021"

Vikas Bahl, N. T. (Director). (2011). Chillar Party [Motion Picture].

Wojcik-Andrews, I. (2000). Children's Films: History, Ideology, Pedagogy and Theory. NewYork: Garland. 